\title{
The Relationship Between Young Populations, Life Expectancy at Birth, Number Of Doctors and Health Expenditure in Turkey: An Econometric Application
}

\section{Tuğay GÜNEL ${ }^{1}$}

\section{ARTICLE INFO}

\section{Article History:}

Date Submitted: 15.11.2017

Date Accepted: 20.12.2017

JEL Classification:

$\mathrm{I} 10$

H51

C13

Keywords:

Health Expenditure,

Health Policy,

Vector Error Correction

Model,

Johansen Cointegration

Test

\begin{abstract}
Health care expenditure is a major health policy concern worldwide. To assist decision-makers in finding best policies to manage health care cost, it is important to understand the factors that affect health care expenditure. The objective of this study is to analyze the effects of youth population aged less than 15, life expectancy at birth and doctors providing direct care to patients on the health expenditure in Turkey and how they affect the health expenditure in Turkey during 1975- 2013 period. Augmented Dickey Fuller and Phillips-Perron tests are employed to check whether the variables are stationary or not. Then Johansen Cointegration test and VECM approach are employed to investigate the long-run dynamics and short-run relationship between health expenditure and youth population aged less than 15,(POP15) life expectancy at birth(LIFEX) and doctors (DOCTORS) providing direct care to patients.
\end{abstract}

According to results, A unit increase in the POP15 leads to a 1.99 unit decrease in the $\mathrm{HE}$ in the long run, A unit increase in the LIFEX leads to a 0.37 unit increase in the HE in the long run. A unit increase in the DOCTORS leads to a 5.39 unit decrease in the HE in the long run. The coefficient of Error Correction Model, indicating the speed of adjustment to restore equilibrium in the dynamic model and how quickly variables converge to equilibrium, is equal to (-0.160506) and imply that more than $\% 16$ percent of disequilibrium in the previous year corrected in the current year

\footnotetext{
${ }^{1}$ Araştırma Görevlisi, Hacettepe Üniversitesi, İktisadi ve İdari Bilimler Fakültesi, Maliye Bölümü, tugaygunel@hacettepe.edu.tr
} 


\section{Introduction}

With the financial crisis in 2008 , the pressure of public spending on the budget has increased the importance of effective and efficient use of public expenditures. In this context, since health expenditure has a considerable share in public expenditures, it has become the focus of measures aimed at mitigating the pressure on the budget. Therefore, it is important for the health policy to know the factors affecting health spending and how these factors affect health expenditures in order to reduce the pressure on the budget and to make expenditures efficiently. Recent developments such as the aging of the population, the prolongation of life expectancy from birth and the number of doctors employed are experienced in Turkey. Understanding these factors that affect health expenditure is essential to assist decision-makers in finding best policies to manage health care costs. Health expenditure in Turkey, proportion to its GDP, increased from $2.2 \%$ in 1975 to $5.1 \%$ in 2013.

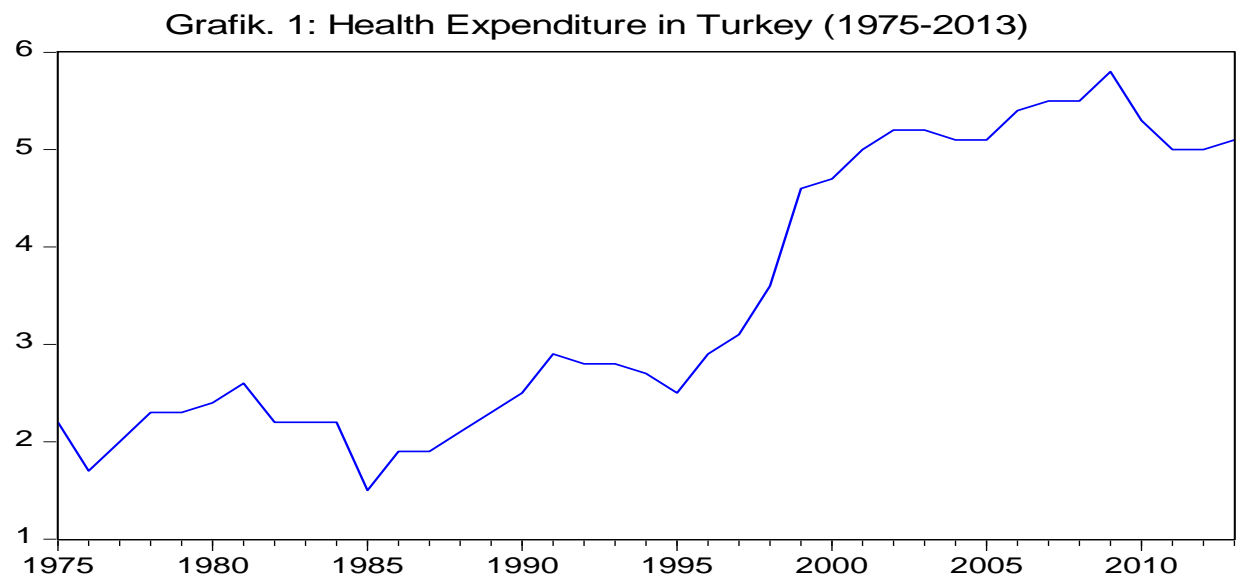

As seen from the Graph 1, health expenditure in Turkey is showing a trend of continuous increase. Especially with the 1994 crisis, this increase has become more prominent since 1995 . In the crisis of 2008, this increase ceased. But from 2010 onwards it tended to decrease.

When we look at literature review in general, factors affecting health expenditures have been examined by various methods. As a result of the studies carried out, there are studies that have reached the conclusion that the young population is not a significant influence on health expenditure, as well as studies that find that the young population is a significant influence on health expenditures (Gbesemete and Gerdtham,1992, Ehikioya(2013) and Fasoranti(2015) ) 
Das and Martin Das and Martin(2010) examined determinants of health expenditure in USA and found that practising doctors does not contribute significantly to the explanation of the healthcare expenditure. When looked at the study made on life expectancy from birth, the results that the health expenditures increase as the expected life expectancy from birth increases. For example, Jaba et al. (2014) and Karagöz and Tetik (2009) concluded that life expectancy at birth has a significant effect on health expenditures.

\section{Literature Reviews}

In the literature, first analysis about the determinants of healthcare expenditure was made by Newhouse (1977), Gbesemete and Gerdtham (1992) found that population under 15 was not significant effects on health expenditure. Bilgel (2004) conducts a study in the Canadian provinces at the period of 1975 to 2000. By using panel data method, he finds that income elasticity of health care expenditure is less than unity. On the other hand, income, share of senior population, and federal transfers have statistically significant effects on the health care expenditure. Dreger and Reimers (2005) investigate the link between health care expenditures, and GDP for 21 OECD Countries by using developed panel cointegration techniques. The study concludes that health expenditure are not only determined by income but also determined by medical progress.In 2009, a study about determinants of health care expenditure in African countries is conducted by Murthy and Okunade (2009). They use ordinary least square (OLS) and two-stage least square (TSLS) method by employing cross-sectional data for the year 2001. The results shows, per capita real GDP and per capita real foreign aid are the major determinants of health care expenditure. Other study in 2009 by Elk et al.(2009) investigate the overview of the literature on health expenditure, and impact of several factors on health expenditure by using an error-correction model. They finds that income and ageing are important drivers of health expenditures. Das and Martin (2010) examined determinants of health expenditure in USA and found that practising doctors does not contribute significantly to the explanation of the healthcare expenditure.

A recent study of 12 Asian Countries, Cambodia, Indonesia, China, Laous, Malaysia, Japan, the Philippines, Singapore, Mongolia, Thailand, Wietnam and South Korea, with the period of 1995-2008 using Panel data estimation by Furuoka et al.(2011) indicate that only 
GDP and POP65, population of 65 and above, have significant relationship with healthcare expenditure in these countries. A comprehensive study that contain economic, demographic, social and political variables by Abbas and Hiemenz(2011) investigate to describe the macroeconomic determinants of health care spending in Pakistan. They analyses time series data from 1972-2006 by employing cointegration, and error correction approach and found one cointegrating vector that means existence of a long-run relationship between public health care expenditure and other variables used in the model. They also find that health care qualifies is a necessity in Pakistan since the income elasticity of public health expenditure is 0.23 which is less than unity. Ehikioya(2013) and Fasoranti(2015) investigated the determinants of health expenditure in Nigeria. They found that population of 15 years and younger and health expenditure share in GDP were the major determianats of health expenditure.

Angko(2013) examined the demand-side macroeconomic determinants of publicly financed healthcare expenditure in Ghana. Error correction model was employed to examine the long-run and short-run relationships within the period 1970-2006 and found that the dominant factor that affect healthcare expenditure was per capita income. Other variables such as age structure of the population and health statutus of the population also affect healthcare. Chaabouni and Abednnadher(2014) examined the determinants of health expenditure in Tunisia during the period 1961-2008. They employed the Autoregressive distributed lag(ARDL) approach and found that there was a stable long-run relationship between per capita health expenditure, GDP, population ageing, environmental quality and medical density. Jaba et all(2014) investigated the relationship between life expectancy at birth and health expenditure per capita by groups of countries with different development levels and geographic positions by using panel data analysis. The study showed a significant relationship between health expenditure and life expectancy.

There have been extensive literatures on health expenditures and its determinants in OECD. However, literatures on Turkey are very few. Uçdoğruk(1996) investigated the health expenditures and its determinants between 1961-1992 and found that population and GDP per capita are important variables that affects health expenditure at the long-run. Another study by Karagöz and Tetik(2009) indicated that previous year health expenditure, infrastructure expenditure and life expectancy at birth had significant impact on health expenditure at the 
long-run. A.K (2012) examined the relationship between public health spending and life expectancy at birth and found that public health spending increases life expectancy. Another study, Akar(2014) investigated the relationship between health expenditure and economic growth by estimating VECM model in the period 2004-2013 and found that a long-lasting relationship between health spending and economic growth.

\section{Data and Methodology}

\section{$\underline{\text { Data Analysis }}$}

Data required for the study were obtained from OECD and they are annual and includes the period 1975-2013 and they were collected on the following macroeconomic variables.

- $\quad$ Population 15 and younger

- $\quad$ Life expectancy at birth

- Health Expenditure

- Doctors

\section{Definition of the Variables}

Our first step to use descriptive and quantitative techniques to analyse the data obtained so it is important to specify the definition and aspects of variables used in this study. According to OECD, the variables used in this study are defined as below.

Health Expenditure: Health expenditure(HE) is defined as the final consumption health goods and services. It includes spending by both public and private sources and this variable measured in percentage of GDP in percentage of total expenditure on healthand in USD per capita (using PPP) (total, US dollars capita).

Doctors: Doctors are defined as practising doctors providing direct care to patients and measured per 1000 inhabitants (Total, per 1000 inhabitants).

POP15: POP15 is defined as youth population aged less than 15 . The youth dependency ratio means that number of young persons that are likely to be dependent on the 
support of others for their daily needs to the number of those who are capable of providing such support. This variable is measured as a percentage of population.

Life expectancy at birth: This indicator is defined as how long, on average, a newborn can expect to live. It is the most frequently used indicator of health status and presented as a total and per gender and is measured in years. The values of the variable mentioned above are shown in the table 1.

Table. 1: Descriptive Statistics, 1975-2013

\begin{tabular}{|l|l|l|l|l|}
\hline & HE & POP15 & DOCTORS & LIFEX \\
\hline Mean & 3.464103 & 32.60769 & 1.068974 & 67.19487 \\
\hline Median & 2.800000 & 32.60000 & 1.100000 & 69.00000 \\
\hline Maximum & 5.800000 & 40.40000 & 1.760000 & 76.60000 \\
\hline Minimum & 1.500000 & 24.70000 & 0.540000 & 56.10000 \\
\hline Std. Dev. & 1.424686 & 5.138420 & 0.389540 & 6.333867 \\
\hline Jarque-Bera & 4.860544 & 3.302681 & 2.831415 & 3.607617 \\
\hline Probability & 0.088013 & 0.191793 & 0.242754 & 0.164671 \\
\hline Observations & 39 & 39 & 39 & 39 \\
\hline
\end{tabular}

Basic descriptive statistics are reported at the table 1. As can be seen from the table, the mean and median of POP15 and DOCT are almost the same, indicating that the distribution of these series are fairly symmetrical. In symmetrical series, the mean, median and mod are equal to each other. (Mean=Median=Mod). Since the median and mean of Health Expenditure (HE) and LIFEX are closely, It could be said that the distribution sample of these series are symmetrical but not fairly. According to Jarque-Bera statistic, all series are normally distributed.

\section{Augmented-Dickey -Fuller Test}

One problem with time series data is that independent variables can appear to be more significant than they actually are if they have the same underlying trend as the dependent variable(Studenmund, 2014:402). Most macro economic time series are trended and so they are 
nonstationary in most cases. If any analysis is made with nonstationary data, the analysis will face a spurious regressions since the Ordinary Least Square (OLS) can lead to incorrect conclusions. Inspurious regression, the value of both $R^{2}$ and " $\mathrm{t}$ " ratios are very high while the variables used in the analysis have no interrelationships. To avoid this spurious regression problem, The data must be checked whether they contain unit root or not. For this purpose, Dickey and Fuller $(1979,1981)$ devised a procedure to formally test for non-stationary. To explain how the Dickey-Fuller test process, consider the following simple AR(1) model of form:

$y_{t}=\varphi y_{t-1}+\mu_{t}$

The condition of stationary is that:

If the $\varphi$ is less than 1 , the series is stationary

If the $\varphi$ is equal to 1 , the series is nonstationary

The different form of the test can be shown by subtracting $y_{t-1}$ from both sides of (1)

$y_{t}-y_{t-1}=\varphi y_{t-1}-y_{t-1}+\mu_{t}$

$\Delta y_{t-1}=(\varphi-1) y_{t-1}+\mu_{t}$

$\Delta y_{t-1}=\alpha y_{t-1}+\mu_{t}$

$\alpha$ denote $(\varphi-1)=\alpha=(\varphi-1)$

Then null hypothesis is $H_{0}: \alpha=0$ and the alternative hypothesis is $H_{a}: \alpha<0$, that means

$H_{0}=$ The series has a unit root

$H_{a}=$ The series has not a unit root

Dickey and Fuller (1979) also proposed two alternative regression equations that can be used for testing for the presence of a unit root. First equations is with constant:

$\Delta y_{t-1}=\beta_{0}+\varphi y_{t-1}+\mu_{t}$

Second equations is with constant and a non-stochastic time trend:

$\Delta y_{t-1}=\beta_{0}+\beta_{2}+\varphi y_{t-1}+\mu_{t}$

The conventional " $t$ " distribution is not used in this test. Instead Mckinnon(1991) critical values are used for each of the three above models. If the DF statistical value is less 
than absolute critical value, the null hypothesis is rejected. That means $y_{t}$ is a stationary process.

\section{Johansen Cointegration Test}

Cointegration analysis can be used to evaluate the co-movement of a long-term of the variables used in the model. If the cointegrating analysis indicates that there is a cointegrating vector, we infer that the tested series will not drift apart in the long-term, and will revert to equilibrium levels following any short-term drift that may take place (Maggiora and Skerman, 2009:16). In cointegration analysis, two main cointegration tests are used:

\section{Engle-Granger Method}

2.Johansen's Cointegration Method using the Trace statistic and/or the Maximum Eigenvalue statistic

In this study, Johansen's method is used because of the shortfalls of Engle- Grangers method that can only be run on a maximum of two variables. It also does not allow for hypothesis testing on the cointegrating relationships, unlike Johansen's method (Brooks 2008). In the Johansen (1988) cointegration test, the series equation system, which is stationary at the same order, is based on VAR (Vector Auto Regression). The system of equations is defined as follow:

$\Delta X_{t}=\Gamma_{1} \Delta X_{t-1}+\cdots+\Gamma_{k-1} \Delta X_{t-k}+\Pi X_{t-1}+\epsilon_{t}$

$\Gamma_{i}=-I+\Pi_{1}+\cdots+\Pi_{i}, i=1, \ldots k$.

$\Pi$ is a matrix of coefficients and indicates how many cointegration relations are in the system of equations. If the rank of the matrix $\Pi$ is equal to 0 , then this means that there is no cointegration relationship between the variables that make up the vector $\mathrm{X}$. If the rank on the other side is equal to 1 , then, there is 1 cointegration relationship between the variables. If it is greater than 1, It is decided that there is more cointegration relations than 1.

In the Johansen Cointegration test, two test are used to establish the cointegration relation between the variables: 


$$
\begin{aligned}
& \lambda_{\text {trace }}^{(r)}=-T \sum_{i=r+1}^{n} \ln \left(1-\lambda_{i}\right) \\
& \left(\lambda_{\max }^{(r, r+1)}=-T \ln \left(1-\lambda_{i+1}\right)\right.
\end{aligned}
$$

Trace test and max test are used to determine the cointegrating relationships at Johansen approach. The Trace test has the null hypothesis:

$H_{0}=$ There are at most $r$ positive eigenvalues

Against the alternative hypothesis

$H_{a}=$ There are more than $r$ positive eigenvalues.

The test statistic is formalized by

$\operatorname{Tr}(r)=-\sum_{i=r+1}^{K} \operatorname{In}\left(1-\lambda_{i}\right)$

TheN max test investigates whether there are $r$ or $r+1$ cointegrating vectors. The null hypothesis is

$H_{0}=$ There are exactly $r$ positive eigenvalues

This test uses the following statistic:

$\lambda \max (r, r+1)=-T \operatorname{In}(1-\lambda r+1)$

The series of test starts with $\mathrm{r}=0$ and is performed until the value of " $\mathrm{r}$ " which is associated with a test statistic that exceeds the displayed critical value provided by Johansen and Juselius (1990). 
As a result, the alternative hypothesis is compared with the basic hypothesis, which expresses that ranks are initially equal to " $r$ " or greater than " $r$ ". As a result of comparison, if the test statistic values are greater than the critical values, the basic hypothesis is rejected. It means that there is a cointegration relation between these variables.

\section{Empirical Results}

Augmented Dickey- Fuller (ADF) (1979) and Phillips Perron (1988) tests are used to test the null hypothesis of unit root for all series. Using Augmented Dickey-Fuller test, each series tested for the presence of unit root. As seen from the table 2, test statistics suggest the presence of a unit root in the level, while first differencing the series yields the apparent lack of a unit root. First differencing makes the series stationary. As a result, according to ADF test, all series are integrated of one $(\mathrm{I}(1))$.

Table. 2: ADF Unit Root Tests Results

\begin{tabular}{|l|l|l|l|l|l|}
\hline & Level & Prob. & $\begin{array}{l}\text { First } \\
\text { Difference }\end{array}$ & Prob. & $\begin{array}{l}\text { Order } \\
\text { of } \\
\text { Integra } \\
\text { tion }\end{array}$ \\
\hline Variables & $\begin{array}{l}\text { Intercept } \\
\text { and Trend }\end{array}$ & & Intercept & & \\
\hline HE & -1.8540 & 0.6583 & -5.7144 & 0.0000 & I(1) \\
\hline LIFEX & -0.9199 & 0.9431 & -3.6551 & 0.0093 & I(1) \\
\hline POP15 & -3.4010 & 0.0671 & -3.0057 & 0.04 & I(1) \\
\hline DOCT & -2.2736 & 0.4374 & -4.9377 & 0.0003 & I(1) \\
\hline
\end{tabular}

Results of Phillips-Perron test is seen from the table 3. Phillips Perron test gives the same results as ADF test. All series have a unit root in the level, but after first differencing all series become stationary. We then check for the presence of cointegrating relations between the 
series. Johansen Cointegration test was used to investigate whether there is a cointegration between health expenditure, lifexpbirth, population of 15 and doctors.

Table. 3: Phillips-Perron Test Results

\begin{tabular}{|l|l|l|l|l|l|}
\hline & Level & Prob. & $\begin{array}{l}\text { First } \\
\text { Difference }\end{array}$ & Prob. & $\begin{array}{l}\text { Order of } \\
\text { Integratio } \\
\text { n }\end{array}$ \\
\hline Variabe & $\begin{array}{l}\text { Intercept and } \\
\text { S }\end{array}$ & & Intercept & & \\
\hline Trend & -2.1170 & 0.5202 & -5.7657 & 0.0000 & I(1) \\
\hline LIFEX & -1.2225 & 0.8913 & -3.8845 & 0.0050 & I(1) \\
\hline POP15 & -1.8198 & 0.6753 & -7.0024 & 0.0000 & $\mathrm{I}(1)$ \\
\hline DOCT & -2.2490 & 0.4502 & -4.9319 & 0.0003 & $\mathrm{I}(1)$ \\
\hline
\end{tabular}

The existence of a long-term equilibrium relationship between the series was then investigated according to the cointegration method developed by Johansen (1988) and Johansen \& Juselius (1990), after they were found to be stationary in the first differences of the series. Before the cointegration test is applied, a VAR model without constraints is estimated by using the variables used in the model to determine the number of lags. From the estimated VAR models, it was decided that the appropriate lag length according to Schwarz Information Criteria (SC) and Hannan-Quinn (HQ) criteria is $\mathrm{k}=1$.

Johansen (1988) and Johansen \& Juselius (1990) cointegration test results with the specified lag length are given in table 4 . When Table 4 is examined, the calculated trace test and the comparison of the maximum eigenvalue statistics with the critical values reveals that there is 1 cointegration vector at the $5 \%$ significance level. In other words, the zero hypothesis that denotes that there is no cointegration vector between the series is rejected by the trace and maximum eigenvalue tests. In addition, since the calculated test statistics are smaller than the corresponding critical value, the null hypothesis that denotes $r \leq 1, r \leq 2$ and $r \leq 3$ cannot be 
rejected. According to these results, it is possible to mention that there is a long-run equilibrium relationship between the series in the analysis period.

Table. 4: Johansen Cointegration Test Results

\section{Variables: HE, LIFEX, DOCT, POP15}

Lags: (1)

\begin{tabular}{|l|l|l|l|l|l|l|l|}
\hline \multicolumn{3}{|c|}{ Trace Statistics } & \multicolumn{5}{c|}{ Max-Eigen Statistic } \\
\hline$H_{0}$ & $H_{1}$ & $\begin{array}{l}\text { Test } \\
\text { Statistic }\end{array}$ & $\begin{array}{l}5 \% \\
\text { Critical } \\
\text { Value }\end{array}$ & $H_{0}$ & $H_{1}$ & $\begin{array}{l}\text { Test } \\
\text { Statistics }\end{array}$ & $\begin{array}{l}5 \% \\
\text { Critic } \\
\text { al } \\
\text { Value }\end{array}$ \\
\hline $\mathrm{r}=0$ & $\mathrm{r} \geq 1$ & $76.10^{*}$ & 63.87 & $\mathrm{r}=0$ & $\mathrm{r} \geq 1$ & $36.62^{*}$ & 32.11 \\
\hline $\mathrm{r} \leq 1$ & $\mathrm{r} \geq 2$ & 39.47 & 42.91 & $\mathrm{r} \leq 1$ & $\mathrm{r} \geq 2$ & 18.73 & 25.82 \\
\hline $\mathrm{r} \leq 2$ & $\mathrm{r} \geq 3$ & 20.74 & 25.87 & $\mathrm{r} \leq 2$ & $\mathrm{r} \geq 3$ & 14.92 & 19.38 \\
\hline $\mathrm{r} \leq 3$ & $\mathrm{r} \geq 4$ & 5.81 & 12.51 & $\mathrm{r} \leq 3$ & $\mathrm{r} \geq 4$ & 5.81 & 12.51 \\
\hline
\end{tabular}

*Denotes rejection of the hypothesis egn at the 0.05 level, Trace and Max-Eigen statistics indicate one cointegration at the 0.05 level

Table. 5: Normalized Cointegrating Coefficients

\begin{tabular}{|l|l|l|l|}
\hline HE & POP15 & LIFEX & DOCTORS \\
\hline 1.000000 & 1.995505 & -0.379971 & 5.396433 \\
& $(0.35838)$ & $(0.12973)$ & $(3.8209)$ \\
\hline
\end{tabular}

The results are normalized on the HE. Due to the normalization process, the signs are reversed to enable proper interpretation. Coefficients are interpreted as follows: 
- $\quad$ A unit increase in the POP15 leads to a 1.99 unit decrease in the HE in the long run

- $\quad$ A unit increase in the LIFEX leads to a 0.37 unit increase in the HE in the long run

- $\quad$ A unit increase in the DOCTORS leads to a 5.39 unit decrease in the HE in the long run

After determining the long-run relationship between the variables in the model, Vector Error Correction model was estimated for short-run analysis. The results of short term error correction model estimation are given in table 6.

Table 6. Vector Error Correction Model Estimation

\begin{tabular}{|l|l|l|l|l|}
\hline Variables & Coefficient & $\begin{array}{l}\text { Standart } \\
\text { errors }\end{array}$ & t- statistic & Probability \\
\hline$E C T_{-1}$ & $\mathbf{- 0 . 1 6 0 5 0 6}$ & 0.04966 & -3.23194 & $\mathbf{0 . 0 0 2 9} * * *$ \\
\hline$D(H E(-1))$ & -0.087023 & 0.14855 & -0.58583 & 0.5622 \\
\hline $\begin{array}{l}\text { (POP15(- } \\
1))\end{array}$ & 0.112135 & 0.27751 & 0.40408 & 0.6889 \\
\hline $\begin{array}{l}\text { D(LIFEX(- } \\
1))\end{array}$ & -0.024325 & 0.12441 & -0.19552 & 0.8463 \\
\hline $\begin{array}{l}\text { D(DOCTORS } \\
(-1))\end{array}$ & -1.513022 & 1.71333 & -0.88309 & 0.3840 \\
\hline
\end{tabular}

*** Denotes significant at the $1 \%$ level

Theoretically, Error Correction Term (ECT) indicates the speed of adjustment to restore equilibrium in the dynamic model and shows how quickly variables converge to equilibrium. For that, ECT must be negative and statistically significant (Pahlavani et al. 2005:13). According to the results of the error correction model estimation, the error correction term $\left(E C T_{-1}\right)$ is negative and statistically significant. This means that if there is a long cyclical 
deviation between these variables, the deviation is eliminated at a rate of $16 \%$. In the short term the independent variables are not significantly different from zero. This indicates that the effects of the variables included in the model on the health expenditures are lost in the short term. This can be explained by the fact that health expenditures are long-term investments.

\section{Discussion}

The existence of a long-term relationship between the variables used in the model and the health expenditures has been demonstrated by the Johansen Cointegration test. In other words, variables affect health expenditures in the long-term. LIFEX influences health expenditures in the positive direction, whereas POP15 and DOCTORS influence the negative direction. The VECM model was estimated for short-run analyzes after the existence of a longterm relationship between variables was determined. The predicted $E C T_{-1}$ was negative and statistically significant. That is, if there is a deviation between the variables in the long run, it will come back to balance.

\section{Conclusion}

In this study some factors that affect health expenditure is analyzed. Firstly Augmented Dickey-Fuller and Phillips-Perron tests were used to specify whether the variables have a unit root or not. The result show that variables have unit root and the same order of integration (I(1)). Therefore, Johansen Cointegration test was used to investigate whether there is a long-run relationship between variables, and it is found that the variables were cointegrated, so the Error Correction Model was built to estimate the short-run coefficients of variables.

According to results, a unit increase in the DOCTORS leads to a 5.39 unit decrease in the HE in the long run. That means increasing the number of doctors will lead to decrease the health expenditure since increasing the supply of doctors will increase the level of health services and will reduce the price of health care services. As a result, the efficiency of health services will also be increase. An increase in doctors employment may have significant implications for health expenditures. Productivity will increase primarily in health services, and at the same time the quality of service, responsiveness to the illness and waiting period will be positively affected. A unit increase in the LIFEX leads to a 0.37 unit increase in the HE in 
the long run. A unit increase in the POP15 leads to a 1.99 unit decrease in the HE in the long run. That means an increase in population of 15 and younger will decrease the health expenditure. Because younger individuals generally bear a lesser burden of murbidity than older individuals (Swinburn and Davis, 2013:31). The coefficient of $E C T_{-1}$ is equal to $(-0,160506)$, and imply that more than $\% 16$ percent of disequilibrium in the previous year corrected in the current year.

\section{REFERENCES}

ABBAS, F., \& HIEMENZ, U. (2011). Determinants of Public Health Expenditures in Pakistan. Zef-Discussion Papers On Development Policy,(158).

AKAR, S. (2014). Türkiye'de Sağlık Harcamaları, Sağlık Harcamalarının Nisbi Fiyatı Ve Ekonomik Büyüme Arasındaki İlişkinin İncelenmesi. Yönetim, 311.

ANGKO,W.(2013). Determinants Of Healthcare Expenditure In Ghana. Journal Of Economics And Sustainable Development, 4(15).

BILGEL, F. (2004). The Determinants Of Canadian Provincial Health Expenditures: Evidence From Dynamic Panel (Doctoral Dissertation, University Of Saskatchewan Saskatoon, Canada).

BROOK, C.(2008). Introductory Econometrics For Finance, Cambridge University Press, 2.Ed.

CHAABOUNI, S., \& ABEDNNADHER, C. (2014). The Determinants Of Health Expenditures In Tunisia: An Ardl Bounds Testing Approach. International Journal Of Information Systems In The Service Sector (Ijisss), 6(4), 60-72.

DAS, A., \& MARTIN, F. (2010). An Econometric Analysis Of The Us Health Care Expenditure. Global Journal Of Health Science, 2(1), 150.

DICKEY, D. A., \& FULLER, W. A. (1979). Distribution Of The Estimators For Autoregressive Time Series With A Unit Root. Journal Of The American Statistical Association, 74(366a), 427-431. 
DICKEY, D. A., \& FULLER, W. A. (1981). Likelihood Ratio Statistics for Autoregressive Time Series With A Unit Root. Econometrica: Journal Of The Econometric Society, 1057-1072.

DREGER, C., \& REIMERS, H. E. (2005). Health Care Expenditures in Oecd Countries: A Panel Unit Root And Cointegration Analysis.

EHIKIOYA, L. (2013). “Determinants Of Public Health Care Expenditure In Nigeria: An Error Correction Mechanism Approach”. International Journal of Business And Social Science, 4(13)

ELK, V. R., MOT, E.P., \& FRANSES, H.P. (2009). Modelling Health Care Expenditures. Cpb Discussion Paper. No: 121.

FASORANTI, M. M. (2015). “An Econometric Analysis Of The Determinants Of Government Health Expenditures In Nigeria”. Journal Of Empirical Economics, 4(4), 193-206.

FURUOKA, F., YEE, B. L. F., KOK, E., HOQUE, M. Z., \& MUNIR, Q. (2011). What Are The Determinants Of Health Care Expenditure? Empirical Results From Asian Countries. Sunway Academic Journal, 8, 12.

GBESEMETE, K. P., \& GERDTHAM, U. G. (1992). Determinants of Health Care Expenditure In Africa: A Cross-Sectional Study. World Development, 20(2), 303-308.

JABA, E., BALAN, C. B., \& ROBU, I. B. (2014). The Relationship Between Life Expectancy At Birth And Health Expenditures Estimated By A Cross-Country And Time-Series Analysis. Procedia Economics And Finance, 15, 108-114.

JOHANSEN, S. (1988). “Statistical Analysis Of Cointegration Vectors”. Journal Of Economic Dynamics And Control, 12, 231-254.

JOHANSEN, S., \& JUSELIUS, K. (1990). Maximum Likelihood Estimation and Inference On Cointegration-With Applications To The Demand For Money. Oxford Bulletin Of Economics And Statistics, 52(2), 169-210 
KARAGÖZ, K., \& TETIK, N. (2009). Factors Determinants Of Public Health Expenditures: An Econometric Evaluation. Econanadolu.

MURTHY, V. N., \& OKUNADE, A. A. (2009). The Core Determinants Of Health Expenditure In The African Context: Some Econometric Evidence For Policy. Health Policy, 91(1), $57-62$.

NEWHOUSE, J.(1997). "Medical-Care Expenditure: A Cross-National Survey”. The Journal Of Human Resources, 12(1), 115-125.

PAHLAVANI, M., WILSON, E., \& WORTHINGTON, A. C. (2005). Trade-Gdp Nexus In Iran: An Application Of The Autoregressive Distributed Lag (Ardl) Model.

PHILLIPS, P.C.B., \& PERRON, P.(1988). Testing For A Unit Root In Time Series Regression, Biometrika, 75(2). 335-346.

RENGIN, A. (2012). “The Relationship Between Health Expenditures And Economic Growth: Turkish Case”. International Journal Of Business Management \& Economic Research, 3(1).

SKERMAN, R., \& DELLA M. D. (2009). Johansen Cointegration Analysis Of American And European Stock Market Indices: An Empirical Study,

SWINBURN, A. T., \& DAVIS, M. M. (2013). Health Status-Adjusted Life Expectancy And Health Care Spending For Different Age Groups In The United States. Mich J Public Aff, 10, 30-43.

STUDENMUND, A. H. (2000). Using Econometrics: A Practical Guide , . 6. Ed.

ÜÇDOĞRUK, Ş.(1996). “The Econometric Analysis Of The Health Expenditures In Turkey: A Multicointegration Test”. Ekonomik Yaklaşım, 7(21), 101-112. 